\title{
拡大中頭蓋窩法（慶大変法）による聴神経腫瘍手術
}

\section{塩原 隆造}

\section{A Modified Extended Middle Cranial Fossa Approach for Acoustic Tumors}

\author{
Ryuzo SHIOBARA \\ Department of Neurosurgery, Keio Lnizersity, Tokyo $\overline{\mathbf{T}} 160$
}

\begin{abstract}
Summary
A modified extended middle cranial fossa approach for acoustic tumors as well as surgical techniques and surgical results are described in detail. 'This method is based upon a combination of Morrison and King's translabyrinthine-transtentorial approach and Bochenek's extended approach through the middle cranial fossa. It has the following advantages: 1) operation can be done in the supine position; 2) it is the shortest approach to the cerebellopontine angle; 3 ) it yiclds a more favorablc operative field and enables easier operative procedurc in the internal auditory canal; 4) cven large tumors can be excised in one-stage operation; 5) it is easy to identify and preserve the facial nerve, the anterior inferior cerebellar artery, and its loop in the posterior cranial fossa; and 6) tumors can be orthoptically isolated and safely and certainly excised without compressing the cerebellum and brain stem.

There were no hospital deaths in 29 patients who were treated by this operative method. Total and radical removal were performed in 21 patients $(78 \%) ; 13$ of $19\left(68{ }_{0}^{\circ}\right)$ large tumor cases $(9$ total removal and 4 radical removal), $2(100 \%)$ medium-sized tumors, and $6(100 \%)$ small tumors localized in the intcrnal auditory canal.

The facial nerve was anatomically preserved in the posterior cranial fossa and the internal auditory canal from 19 $(70 \%)$ of the 29 cases; $14(69 \%)$ of the 21 cases which received total removal or radical removal, and $8(62 \%)$ of the large tumor 13 cases. Intracranial end to end anastomosis was conducted in 2 of 8 sacrificed facial nerves, and facial-hypoglossal anastomosis was conducted in the remaining 6 cases, onc week after the operation. Long-term follow-up of facial ncrve function rcvealed that 26 of the 27 cases were normal or satisfactory. As for postoperative complications, 3 cases of CSF leakage (one of them was surgically occluded, and the rest healed spontaneously), and one case of postoperative hemiparesis were observed. There was no postoperative temporal epilepsy or aphasia.

This method, that is, the neurosurgical-otological team approach, is compared with other methods, and advantages and superiorities of this method are emphasized.
\end{abstract}

Key words: acoustic tumor, facial nerve, cerebellopontine angle tumor, middle cranial fossa approach, transtentorial-translabyrinthine approach

\section{I はしめに}

聴神経腫瘍に関して1777年 Sandifort ${ }^{48)}$ が最初の剖検

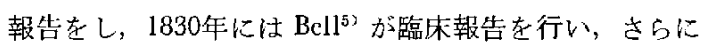
1894年 Ballance ${ }^{4)}$ がはじめて後頭下開頭により聴神絓腫
瘍の手術成功例を報告した．以来 1 世紀近く聴神経腫瘍 に刘し，より安全より完全な手術手技を求めて多くの手 術法が行われてきた，今日までの聴神経腫癔の基本的な アプローチは経後頭蓋窩法, 释迷路法, 中頭蓝營法であ り，その他この三者を組合わせた合傡法がある、今世紀

\section{慶応義塾大学譄神経外科 \\ [速絡先： $\mathbf{T} 160$ 東京都新宿区信濃町 35 , 慶忍義塾大学脳神経外科, 塩原隆造] \\ 1979年 9 月 19 日 受稿}


Table 1 Summary of surgical approaches to acoustic neurinoma

\begin{tabular}{clc}
\hline 1962 & Suboccipital approach & 34 \\
& $\begin{array}{l}\text { Microsurgical suboccipital } \\
\text { translabyrinthine approach }\end{array}$ & 8 \\
& Translabyrinthine approach & 7 \\
$\forall$ & $\begin{array}{c}\text { Combined suboccipital } \\
\text { translabyrinthine approach }\end{array}$ & 4 \\
1975 & Middle cranial fossa approach & 3 \\
$1976 \sim$ & Modified extended middle \\
1979 & cranial fossa approach & 27 \\
\hline & Total cascs
\end{tabular}

初頭寺でにこれらの基本的アプローチは等人澾6)1118)191 3933451)により行われ，その後，後頭下法は Cushing ${ }^{123}$ 加 5 Dandy (1941) ${ }^{14)}$ 程て一応完成されたが，後頭卜法 の手術死亡率は Rcvilla ${ }^{46)} 22.1 \%$ (1947), Horrax \& Poppen $^{24} 14.1 \%$ (1949), Mckenzie \& Alexander ${ }^{35} 12.5$ $\%$ (1955), Pool \& Pava ${ }^{411} 20.7 \%$ (1957) と高〈, House ${ }^{25)}$ は1961年手術顥微鏡を使用して経迷路法再導入し好成 續を上げた。しかし経迷路法洼径 $2 \mathrm{~cm}$ 以上の大腫瘍 に対方䓃適用が困難であり，一力後頭下法はRand \& Kurze $^{452}$ の手術用頙微鏡使用で手術成績の向上在みたが，

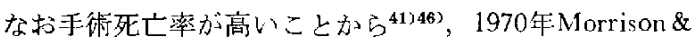

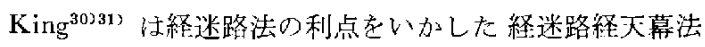
在行い，1.7\% と低い手術死亡率索友，Bochenek れを modify し，むしろ中頭蓋窝法を主体とした拉大中 頭蓋窝法を行った。

著者らは 1975年むで種々の手術泣夌行ったが（Table 1)，腫瘍の大きさによる手術法の選択の問題288533をも 解決するため神経耳科と協同て Morrison \& King と Bochenek の方法各合任した㹡大中頭蓋窝法（鹿大変法） modified extended middle cranial fossa approach ${ }^{2829)}$ t 1976年より行っている。最近 3 年間に㯖神経腫瘍27例を 含む小脳橋角部腫瘍33例に対してこの手術法を行い，沙 足す心゙き結果安得ているので本手術法の詳細を述べ，他 の手術法とD比較検討を行ら。

\section{II 手術手技}

\section{1. 術前処置}

原則として他の一般開頭術の術前処置に準し，本手術 に特別な術前処置の必要はない，術前内脸水腫が著明な ときのシャント手術は本シリーズでは 2 例儿行われた。 また術淔前に前角穿刺に上る脸宝ドレナージや，腰椎穿 刺による䯣液排出を行 5 必要はなく，本シリーズ初期の 数例汇術中脳室ドレナージを試行したが現在洼行ってい

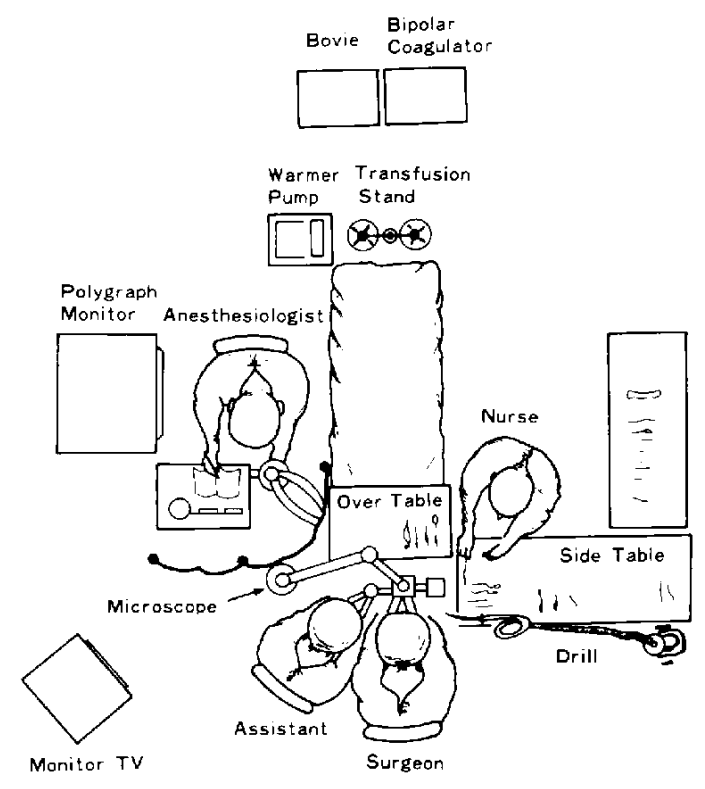

Fig. 1 Room arrangement. Cited from House ${ }^{26)}$ and revised.

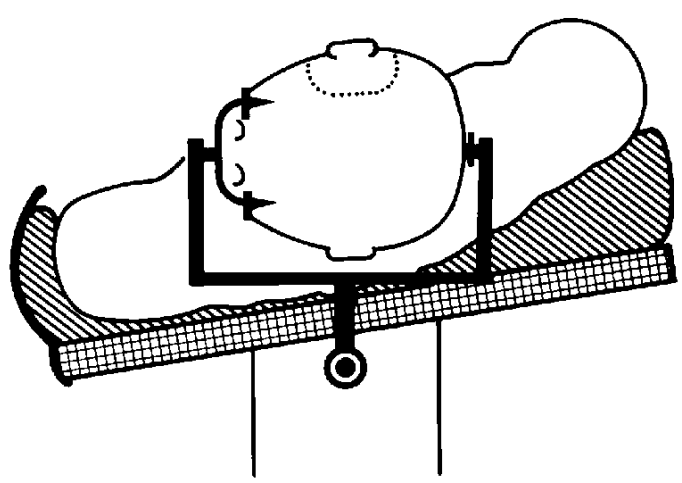

Fig. 2 Position of patient and skin incision.

ない.

\section{2. 麻酔}

気管内拌管麻酔を行い, 手術開始と前後し， $20 \%$ マン ニットール $500 \mathrm{ml}$ の点滴静注を行う.

\section{3. 体位}

手術空内の配置㤌Fig. 1 に示したが，患者は仰卧位 とし頭部注患側を上にほぼ真横とする（Fig. 2)，

\section{4. 皮虎切開・開頭}

皮膚切開屾耳介・外耳孔中心の半円状とし，前方は頉 骨弓中央上縁加ら後方は乳様突起後部に向加い，中頭蓋 底の蕗出が容易となるよう下方へ十分に行う，側頭筋・ 骨膜は皮膚と同様に切開し，外耳孔の直上まで側頭骨か ら剝離し皮膚弁とともに反転する，ついで遊離骨弁を形 


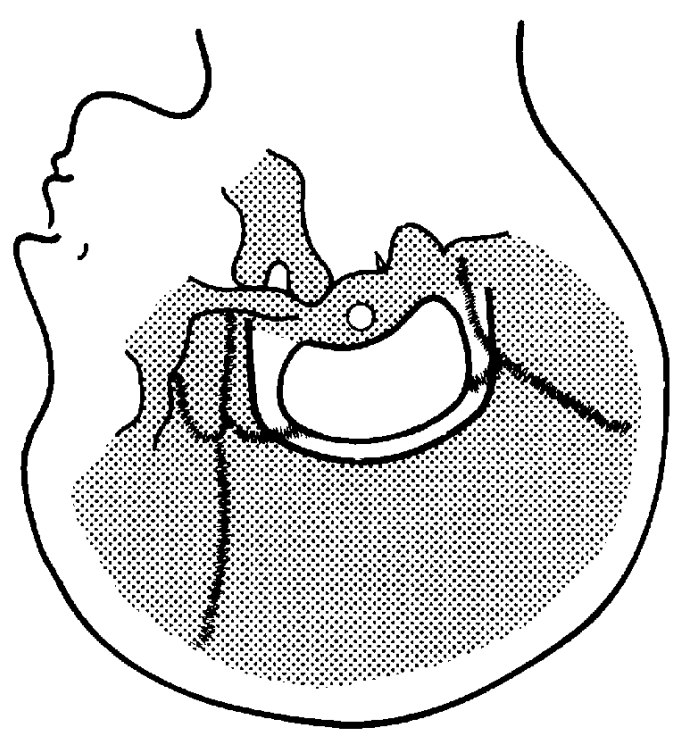

Fig. 3 Skin incision and craniotomy.

成し，さらにロンジュールを用いて中頭盖底面まで骨空 を摭大する，特に後方性乳突蜂紧を一部開放するまで行 5 (Fig. 3).

\section{5. 錐体稜への硬膜外アプローチ}

中頭蓋底より硬膜を錐体稜（上錐体静脈洞溝）に向方 って剥離举上寸る。前方は棘孔までで十分であり，内方 の剝灕は錐体稜，上錐体静脈涧满まで行う(Fig. 4)。石更 膜外アプローチに際し脳圧元進のため硬膜緊張が高度の ときはマンニットールを追加し，硬膜に小切開を加え， 側頭葉底でクモ膜穿破し, 髄液吸引すれば硬膜举上 は容易しなる。

6. 中頭䓝窩経由迷路摘出およひ内耳道開放, 内耳道 内の顔面神経保存と腫瘍摘出

硬膜举上後，錐体面が十分に露出されると中頭蓋䆚释 由に上方加6下方に向加って乳搛突起削開交行い，続い て迷路削開の後に内耳道在開放するのが本法の一つの特 徴である，我々のチームでは錐体部削開と内耳道内手術 操作は主として神経耳科医が行っている。まずカッティ ングバーを用い，錐体上面より下方（乳様突起尖端の方 向）に向加。て乳様突起削開在行与。すなわら乳様乫起 尖端に向加って乳突蜂紧削開し, 内側は後頭蓋䆛の硬 膜を十分露出する。乳様突起の削開法骨皮質在牫 L, 上方から乳様突起をえぐるよに削開するだけでよい (Fig，4，5)。この程度に削開寸れば閉頭時の筋肉片の忘 檤が十分か一確実に行われ，䯠液瘦の防止となる，S 状 静脈洞の外側には, House $\mathrm{e}^{26)}$ が経迷路法で行っているよ らに島状に溥く骨を残すことができる。迷路は外側半規

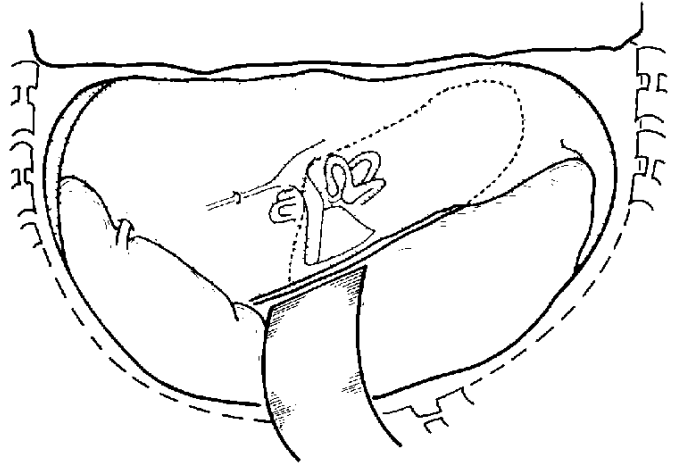

Fig. 4 Extradural approach to the pyramidal ridge or sulcus of superior petrosal sinus through the middle cranial fossa. The removal area of the temporal bone shown by broken line.

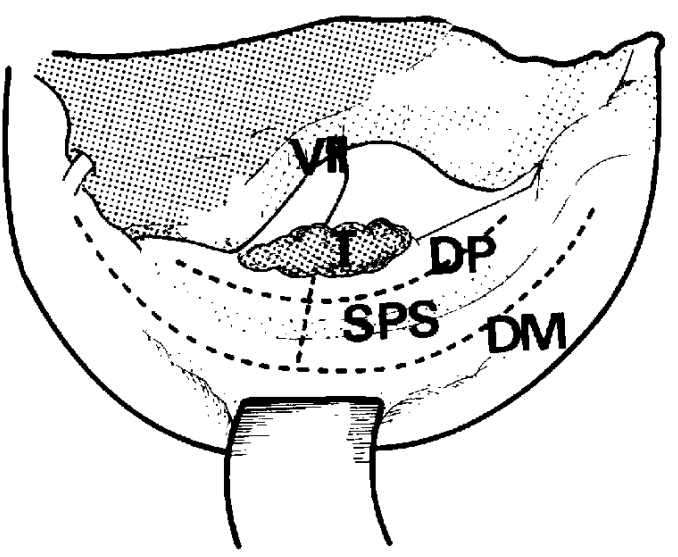

Fig. 5 Removal of the temporal bone and unroofing of the internal auditory canal. The facial nerve and the tumor in the internal auditory canal are illustrated. Broken lines show the dura mater incision of the posterior cranial fossa and the middle cranial fossa, and the division of the superior petrosal sinus.

VII : facial nerve, $\boldsymbol{T}$ : tumor. DP: dura mater of posterior cranial fossa, SPS: supcrior petrosal sinus, DM: dura mater of middle cranial fossa.

管より上・後半規管, 前庭と次々に削開し, 内耳道後壁に 向から。また内耳道上壁の削開が経迷路法より容易なの もこの手術法の利点である。ついでダイアモンドバーを 用い内耳道を開放し，Bill's bar の部位で顔面神経を確 認し, 慎重に顔面神経を保存しつつ内耳道内の腫禓摘出 を行ら (Fig. 5).

腫劰が後頭蓋窩内に $1 \sim 2 \mathrm{~cm}$ 突出している中等大腫 瘍のとき注，程迷路法に準じた内耳道内腫瘄摘出に引き 続き，内耳孔阏边の後頭蓋䆚硬膜を切開寸れば後頭蓋窩 
内腫演の摘出は可能である。また腫㾃が内耳道内に限局 した小腫瘍である場合には，乳様突起削開注行わずに内 耳道上壁のみの削開を行う。内耳道の開放は内耳孔のや や後上方で錐体稜より外側に向加て行う，内耳道開放 後 Bill's bar 上り顔面神経の礁認と保存, 腫陽摘出を行 ら.さらに径 2 5 $\mathrm{cm}$ の後頭蓋窝内の大腫㣀に対して は次に述べる小脳天幕切開を併用し，one-stage に後頭 蓋管内腫瘍の摘出を行らことができる。このように， らゆる大きさの腫瘍に対して順次手術孛抬大できる点が 本法の利点の一つである。この時点で神経耳科医は交代 し，腇神経外科医が以下の手術操作を行う。

\section{7. 硬膜 - 小脳天幕切開上上錐体静脈洞切断}

雓体部の広範な骨削開に加之て次に行方硬膜・小脑天 幕の広範囲切開により，小脳橋伯部の広、手術野加得ら れる。よずFig. 5 の点線に示すよ5に，後頭蓋窞 錐 体 面の硬膜と中頭蓋窝硬膜を上錐体静脈洞索注さ斗行に 切開し，ついで上锥体静脈洞党電気凝回または夕リップ を加け切断，引き続き小脑天幕を切開子る。，小脱天幕切 開は García-Bengochea ${ }^{20)}$ の経天幕法の上5に小脳天幕

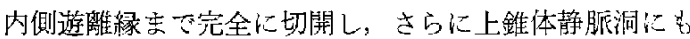
平行に切開する (Fig．6)。この切開にあたっては小檤 天幕遊離縁下自に沿って走行する消東神経在摃偪しない よらな注意が必要である。乳様突起削開，迷路摘出に加 えてこの硬膜・小脳天幕の広範四切開が本法の重要なポ イントでする。これらの操作によって広い手術野が得ら れ，内側方泩腫暍上橋との接触面を直視下に扰き，後力

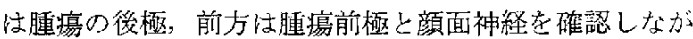
ら腫瘍摘出が可能である(Fig. 7).

\section{B. 後頭蓋窩内腫瘍摘出と顔面神経保存}

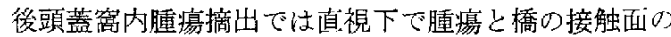
剝放加可能であるが，剝離は慎重であること，前下小脳 動脈々その分枝の摃傷圶避けること，顔面神経を摃穓し ないように操作を進めることが大切である。

1) 後頭蓋㔨内り顔面神経の確認

腫瘍がほぼ露出したら颜面神程を確諮する，解剖学的 にも，腫湯の発育からも顔面神経注多くゆ場合，小脳橋 角部加ら腫瘍の前上才を走り，時には腫瘍の削極周辺や 前下方を走り，内耳道内の前上方 $1 / 4$ 通って内耳道逶 に至る，小脳橋角部の髄膜腫やその他の腫湯の場合，顏 面神経は腫瘍の後上方・後下方に圧排されることはある が，聴神経腫瘍では後方に扸排されることは稀である。

通常, 顔面神経は内耳道内加ら腫瘍表面へ上たどり確認 できるが，腫瘍が大きくなるにつれ，顔面神経は腫瘍表面 で扇状，篣状に抢し搪げられ，腫汪被膜との鑑別はしばし ば困難である。艦別困難なときは強拡大倍率の顕微鏡や

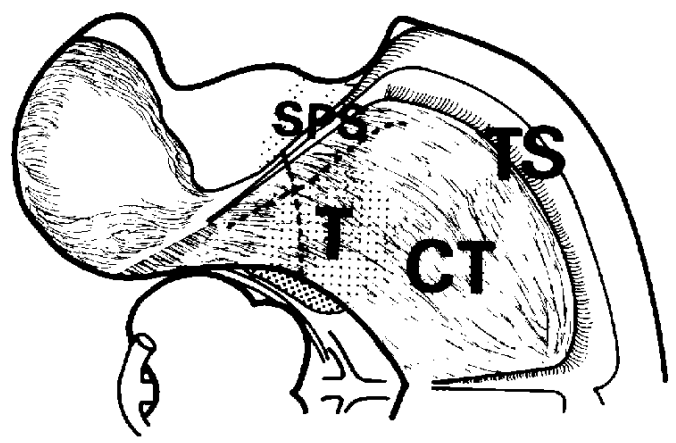

Fig. 6 Incision of the cerebellar tentorium and the superior petrosal sinus shown by broken lines. SPS: superior petrosal sinus, T: tumor, TS : transverse sinus, $\mathrm{CT}$ : cerebellar tentorium.

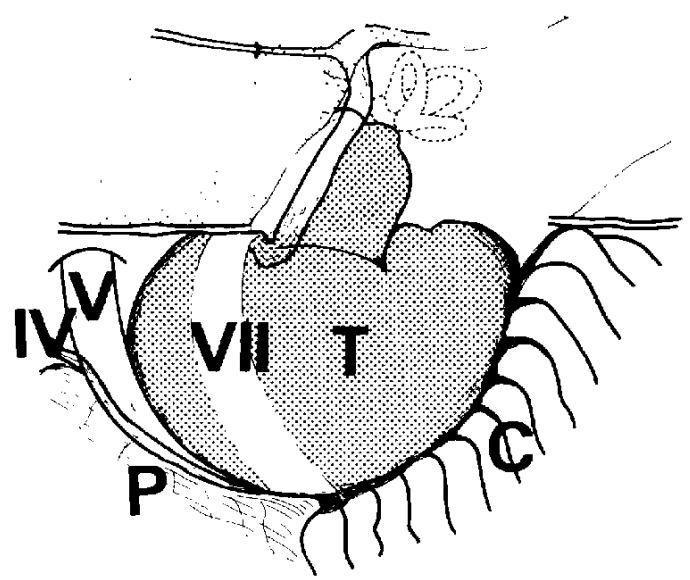

Fig. 7 Tumor and facial nerve in the internal auditory canal and the posterior cranial fossa aftcr incision of the cerebellar tentorium.

IV: trochlear nerve, $\mathrm{V}$ : trigeminal nerve, VII : facial nerve, $\mathrm{T}$ : tumor, $\mathrm{P}$ : pons, $\mathrm{C}$ : cerebellum.

神経電気刺激により顔面神経の確認に努めるが20>36254), それでもな怙鑑别できない場合がある。

2) 後頭蓋䆚内腫痬摘出

腆瘍の摘出はまず piecemeal に被膜内腫榎摘出，腫演 内減圧 ${ }^{(3)}$ を行う。ついで被膜を含め全摘出を行うが，こ の際ま寸颜面神経はその周辺被膜とともに残し，最後に 残存被膜 scrap 顔面神経から㔀離摘出する，橋からの 被膜得離は再発再手術例では困難を伴らが，初回手術例 では容易で, 被膜を軽く引き，双極拱子の先端をていねい に小さく開閉しながら橋と被膜の間に隙間を作るように 行えば安全である.Bipolar electrocautery 浊極力弱くし， なるべく使用を避け，脑幹から腫煌に入る血管のみをシ ヨートバーストで凝固切断し54，微小血管をできるだけ 
温存し、てい杍いに行えばほとんど出血しない，被膜の 剝離摘出が進めば脳底動脈が直視下に現れ，ついで前下 小脑動脈ぶ分岐し，その分枝・ループが被膜の表面に貼 りつくよらに分布している。ループから内耳道一向から 分枝, 内耳動脈・錐体動脈を末梢で切断しループを損傷 しないよらに被膜から剝離する。

\section{3) 後頭蓋咓内顔面神経保存}

最後に顔面神経に附着したまま残していた被膜を摘出 する、この際もっ上も注意走要するのは, 顔面神経が内 耳道に入り込む内耳孔開口部附近である，大腫陽によっ 七顔面神経浽後頭窝錐体面に圧排され，内耳孔開口部 で急角度に屈曲し, 内耳孔辺縁でくびれ内耳道に入るか らである(Fig，7). 大腫瘍では顔面神経は扇状に扗が り被膜との判別が困難なため損傷され易い，神経の損稘 を澼汀万た顔面神経に小被膜をやむをえず残存させ， 根治的摘出 ${ }^{423}$ とすることすある，また被膜摘出中に顔面 神経が切断された場合, Drake ${ }^{16)}$ は頭盖内神経吻合老行 っているが, 本法でも手術野が広いので物合可能であり， 断端を確認しえた 2 例に頭蓋内神経吻合が行われた.

\section{9. 閉頭}

上鼓室が開放されている場合にはここの部に侧頭筋小

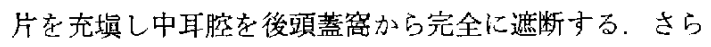
に錐体乳栐部の骨削開部には骨万らと有蒸側頭筋を充㙋

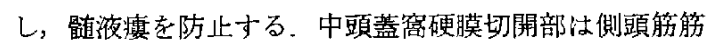
膜あるいは人工硬膜を硬膜に縫合し，骬弁を固定，側頭 筋敕合，皮膚艇合し手術在終る。

\section{III対象之結果}

対象：1975年までのI4年問，56例の聴神経腫瘍には後 頭下法をはじ種々の手術法を行ったが，最近 3 年間の 27例には拡大中頭蓋窝法（慶大変法）を行った（Table 1). 本手術法はさらに聴神経腫瘍以外の小譄橋角部腫瘍 6 例にも行われた (Table 2).27例の聴神経腫瘍の年令 分布沬16 70才生でで, 40 50才台が多く, 平均年令46.5 才であった (Table 3)，27例の5ち男性 13 例，女性 14 例, 手術側法右 13 例, 左14例であるが,このうち3例の neurofibromatosis 中の 2 例恃両側性喱瘍であり，1例は 左側のみ，他の1 例は右側のみに手術が行われた(Table 4). 後頭下法被膜内覀全摘後の再発 2 例に本手術法によ る再手術が行加た。

結果：27例のうち手術死亡は皆無であり, 現在まで退 院後死亡も皆無である。腫瘍の大きさと摘出程度との関 釈は, 径 $2 \mathrm{~cm}$ 以上の大腫瘍 19 例の5ち全摘出 9 例, 顔 面神経に小被膜 scrap を残した根治的摘出 4 例であり， 計13例 $(68 \%)$ に全扝よび根治的摘出が行われた. 径 2
Table 2 Summary of cases treated by the modified extended middle cranial fossa approach to the cerebellopontine angle

\begin{tabular}{llr}
1976 & $\begin{array}{l}\text { Acoustic neurinoma } \\
\text { Epidermoid of cerebellopontine angle } \\
\text { Cancer of dermoid of } \\
\text { cerebellopontine angle } \\
\text { Neurinoma of facial nerve } \\
\begin{array}{l}\text { Meningioma of cerebellopontine } \\
\text { angle }\end{array}\end{array}$ \\
\hline Other & 1 \\
\hline & Total cases & 1 \\
\hline
\end{tabular}

Table 3 Age distribution of 27 cases of acoustic neurinoma

\begin{tabular}{cc}
\hline Age of patients & No. of cases \\
\hline$<19$ & 2 \\
$20-29$ & 0 \\
$30-39$ & 4 \\
$40-49$ & 9 \\
$50-59$ & 10 \\
$60-69$ & 1 \\
$70<$ & 1 \\
\hline Total cases & 27
\end{tabular}

Table 4 Sex and laterality of 27 cases of acoustic neurinoma

\begin{tabular}{ll|lc}
\multicolumn{1}{c|}{ Sex } & \multicolumn{2}{c}{ Laterality } \\
\hline Male & 13 & Right & 12 \\
Female & 14 & Left & 13 \\
& & Bilateral & $2^{*}$ \\
\hline & 27 & & 27 \\
\hline
\end{tabular}

* One of the 2 bilateral cases was operated upon only on the left side, and the other only on the right side.

$\mathrm{cm}$ 以下の中腫瘍 2 例, 内耳道内限局の小腫瘍 6 例, 計 8 例には全例に全摘出が行われ，結局27例中 21 例 $(78 \%)$ に全および根治的摘出を行った. 被膜内亜全摘出にとど 去ったのは大腫演の5ちの6 例であるが, 5ち2 例は後 頭下法被膜内亜全摘出後の再発例で，脳幹部と腫瘍の瘾 着が強く，3例は neurofibromatosis 両側性腫瘍で反対 側の聴力や顔面神経機能を考虑し，術前加ら根治手術， 全摘出は困難と判断された。

顔面神経が後頭蓋窝, 内耳道の再者内でともに形熊上 保存されたものは全27例中の19例70\%，全摘および根治 
Table 5 Operative mortality and postoperative facial nerve function

\section{Facial ncrve function}

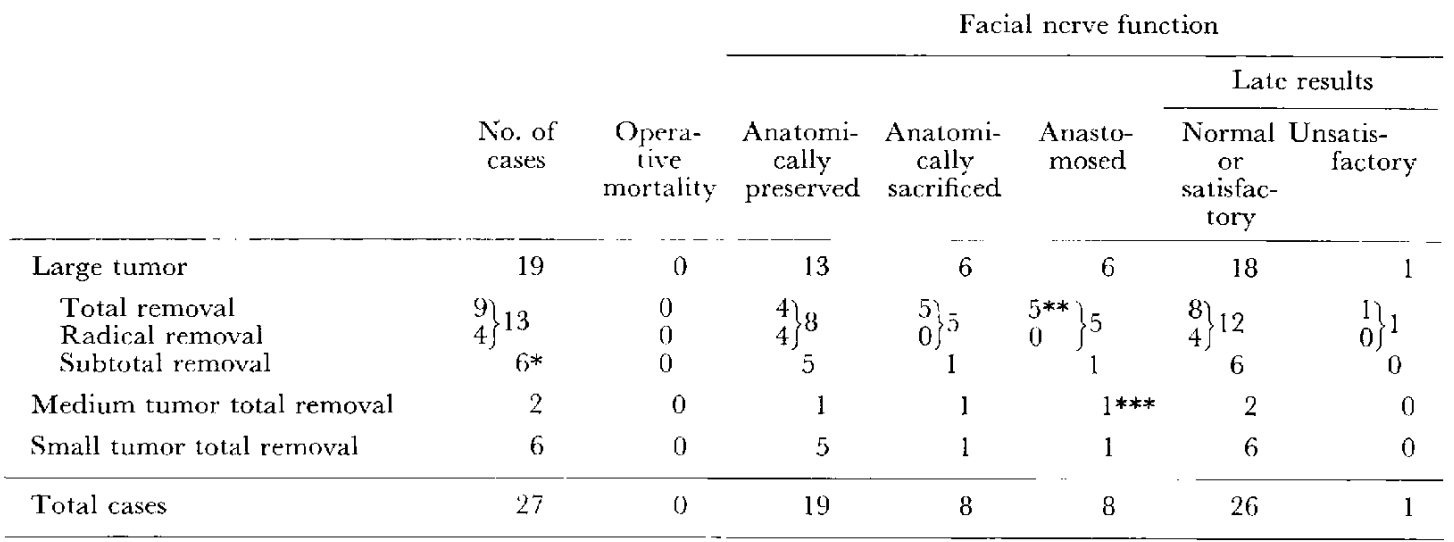

Large tumor: $>2 \mathrm{~cm}$, Medium tumor: $<2 \mathrm{~cm}$, Small tumor: intracanalicular.

Five of the 6* include 2 recurrent cases after suboccipital operation with subtotal intracapsular removal, 2 cases of bilateral acoustic neurinoma of neurofibromatosis, and 1 case in which the patient's condition was poor prcoperatively.

In 2 cases (one of the $5 * *$ cases and $1^{* * *}$ case) intracranial end-to-end anastomosis of the sacrificed facial nerve was conducted during the operation.

In 4 of the $5^{* *}$ cases, facial-hypoglossal anastomosis was performed about one week after the operation.

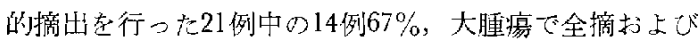
根治的摘出を行った13例中り 8 例 $62 \%$ であり，車全摘出 では被膜内摘出で㚣ることから6例中5例89\%で方っ た。顔画神経が北態上保存さ机たものは術後不全麻痺を みても術後 1 年でほぼ正常に機能回復している。颜面神 経が形態上保存できなかったわのは大腫瘍の全摘山で 4 例，術中確認したが切断されたものが4例であり，後者 O 4 例注大腫煌の全摘出と亚全摘出，中腫瘍の全摘出， 小腫瘍の全摘出の各 1 例であった。結局顔面神経が形態 上保存できなかった 8 例に恃全例神経吻合術が行われ た. そのうちの2 例怯術中頭蓋内で切断端の端々吻命が 行われ，他の6 例は顔面神経舌下神経吻合術が摘出術後 1 週間前後に行㹝れた。顔西神経機能の遠隔战續は吻合 例でも機能回復沬よく，全27例中26例には颜面㿟運動時 に顔面の醜形过残していない(Table 5).

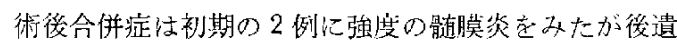
症なく軽快した，術後髄液鼻瘦は 3 例で，亏ち1例江術 翌日儿経迷路性に鼓空を筋肉片を用いて邽允蒖して治

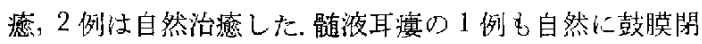
鎖し治撩した，術後の侧頭葉てんかん発生法大腫瘍例に

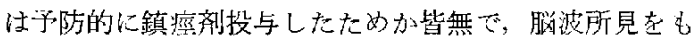
とに鎮㽷剂考順次中止している。 Neurofibromatosis 01 例江, 術後 $\mathrm{C} T$ スキャン上,側頭葉内小血腫索みたが, そ のための症状発現をなく治瘾した， 1 例儿不全片麻煳を みたが失語症在残したもの汢ない，再発再手術例て術後 V-Pシャントを必要としたI例を除いては術後の麻醉
の営醒，意請の回復は良好で，大部分屾術翌日から経口 掫取可能であった。

\section{IV 考察}

1894年に Ballance²がはしめて後頭下開頭による手術 成功列老報告して以来, Stieglitz $\zeta^{511}$ の側頭下释天幕法 (1896)，Cotteril ${ }^{11)}$ の雨側後頭下法 (1898), Panse ${ }^{40)}$ O 経迷路法の示唆 (1904), Fraenkel ら ${ }^{18)}$ の 2 期的徭頚下 法 (1904), Borchard $\mathbf{t}^{\mathrm{B})}$ の片侧後頭下と経迷路合仿法 (1905)，Krause ${ }^{33)}$ の片側徭頭下法 (1909) の試みがなさ れ，Kummel ${ }^{34)}$ が释迷路法 (1909) で监全摘に成功して からは，Quix ${ }^{43)}$, Schmiegelow ${ }^{493}$, Hegner $b^{221}$ により経 迷路法が行わ扎た，また後頭下法法 Cushing ${ }^{12)}$ 被膜内 摘山に繶いて全摘出を主張した Dandy ${ }^{14}$ により1941年 にはほぼ完成し，手術死亡率の低下を办たが，な抢22\% と高率であった。その後Atkinson が前下小脳動脈の重 要性空指摘してから手術死亡率は低下し，また顔面神経 保存汇当重点が执かれるよになった。しかし後頭下法 俚依然opcrative mortality, postoperative morbidity

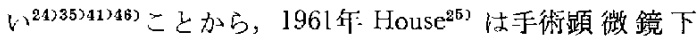
に中頭蓋窩経由経迷路法を再導入し，1965年 Rand \& Kurze $^{45)}$ は microsurgical suboccipital transmeatal operation 老行い，ともに手術成績を著しく向上させた。 しか し小腫㕫に対して経迷路法は優れた手術法るあるが，人 蕾湯に沬不適であり，一方大腫瘍に対する後頭下法汢本 来, 媨幹部前侧面へのアプローチが困難で, 小脑・脳幹部 

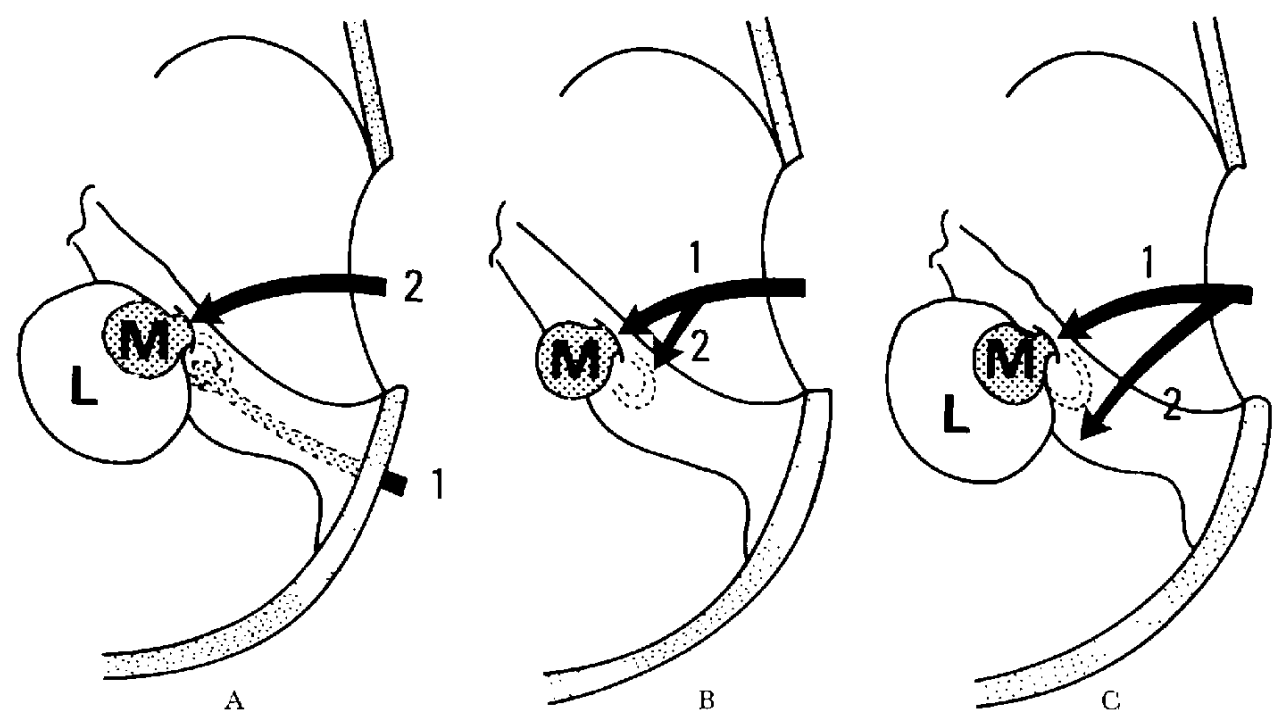

Fig. 8 Surgical approaches (right car). A: Morrison and King, B: Bochenek, C: author's modified method. Numbers indicate the order of the operative procedure. Sizcs of the arrows in B and $C$ indicate the extension of the removed temporal bone.

M: medium tumor, L: large tumor.

○の手術侵襲も少なくなく，手術死亡率は Olivecrona ${ }^{39)}$ 19.2\% (1967), Drake ${ }^{12)} 14.6 \%$ (1967), Rand $^{443} 9.0$ $\%(1969), \quad$ Pool $^{42)} 7.3 \%$ (1970), Northficld ${ }^{38)} 16.0 \%$ (1970) と決して低いものではなかった，小脳・脪幹部 への手術侵襲避ける意味加らも，1970年 Morrison \&

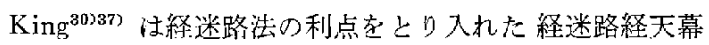

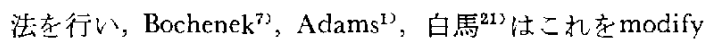
した方法で，李た Rosomoff ${ }^{47}$ ，García-Bengochea ${ }^{203}$ は側 頭下経天幕法を行以高以全摘菜率と低い手術死亡率在得 ている，著者らも過去に種々の手術法を行い，腫㽷の大

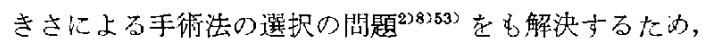
Morrison \& King の方法と Bochenek の方法在折惠した 方法老行い，これを両者と区別するため掂大中頭荎窝法 (慶大変法) modified extended middle cranial fossa approach $^{28) 283}$ として最近 3 年間行ってきた（Fig. 8).

\section{1. 本手術法の利点と他手術法との比較}

従来, 中頭蓋窝経由経天幕法は基本的に侧頭葉挙上や,

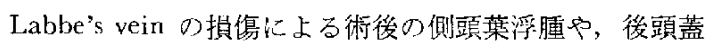
裔の減压が嵝頭下法と比較して不十分である等の理由 で行加れない傾向があるが15>42)，Rosomoff47， GarciaBengochea ${ }^{20)}$ は侧頭下経天幕法で好成績を得ている。一 方後頭下法は小脳の圧排举上や uncapping，㧛幹部への 直接の手術侵襲，さらに前下小兴陲脈 manipulation に よる血柽形成のための䛔後の小畄・脳幹部硬塞, 浮腫, 坐位手術に上る空気塞栓等の久点がある。拉大中頭盖窩 法（慶大変法）では仰卧位手術を行える利点があり，侧
頭葉压迫も少なくてすみ，広範な側碩管削開と小腷灭幕 切開のため後頭蓋密の減圧効果は後䫒下法に劣らない上 辇えられる。ささらに本手術法の利覀を上げると，

i）小脳橋角部入最短距離でること

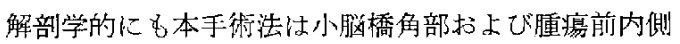
部人は最短距離である。後頭下法ではもっ上も景く、し

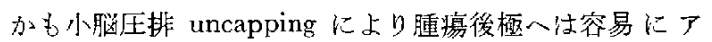
プローチできるが，小脳橋角部方，腫瘍前内側部人はさら に小㮁・腷幹部の正排が必要である。

2)経迷路法より艮好な手術野

内耳道内手術や小腫湐摘出に際しては経迷路法, 中頭 莣筒法は優れたアプローチで岕り, 内耳道这でBill's bar を確認しさらに颜面神経の確認と保存库行うには最迵で あるが52，手術野が狭く，主に耳科的小腫癔に行われて いる，本手術法では小腫瘍に对しても経迷路法，中頭蓋 窝法より広い手街野で内耳道内手術を経迷路法に準して 行うことができ，さらに硬膜・小脳天幕切開によって大 嗹㾴にも適用される。

3) 大腫瘍む one-stage で摘出闩能

後頭蓋简進展が $2 \mathrm{~cm}$ 以下の腫瘍に対して経迷路法が 种経耳科医の好む方法であることから，大腫湟に対して もまず経迷路法を行い，後日 2nd stage として後頭下法 を行う後頭下経迷路合併法を行5ものもあるが23732)36), 本手術法では中頭算窝法を基本とし腫禓の大きさに徒っ て乳様突起削開，迷路摘出，小腷天幕切開上, 順次手衡 野の桩大ができ，大腫湯も one-stage に摘出可能であ 
る.また側頭下経天幕法 ${ }^{20177}$ と比較して本法では錐体部

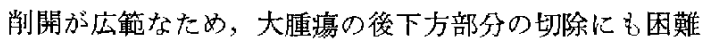
はない。

4) 後頭蓋窝での顔面神経と前下小脎動脈の確認保存 が容易

解剖学的に顔面神経柱内耳道内では前上方 $1 / 4$ 亿位置 し, 後頭蓋简内でも通常, 腫崵の前上面または前極周辺 にある。後頭下法では腫場摘出汇続いて顔面神経は腫婸 の前方かげから現れるが，被膜上の鑑別が困難な大腫瘍 では，顔面神経在確認する以前に盾瘍摘出ととるに損稘 切断の危険が多い：この点本法では腫瘍上面珈らフプロ 一千するため，顔面神経を内耳道内で確認し，引き続き 垕煌表面，小脳橋角部へたどることも可能である。術後 の morbidity にもっ上も関与する前下小脳動脈上そのル ープは variation が多いが350), 多くの聴神経腫煌では腫 瘍の後下面に位置する，そのため後頭下法で流腫瘍表面 で采ずループを確認することが多く，術中絶えずmanipulation の必要があり ${ }^{543}$ ，かえって血管損傷上血栓形成 の危険がある ${ }^{52}$ ， 它の点本法では腫瘍摘出の最後の段階 で被膜から剝離するだけであり，血流障害の危険梳最小

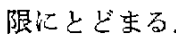

5）小腷・脑幹部を压排せずに直視下で安全な腫焬剝 離摘出が可能

本法では腫瘍の上外側からアプローチし, 腫瘍内減圧 しながら摘出を進めるため，脳幹部に対して絶えず堿恃 しながらの手術となる。しかる脂幹部と被膜との接触画

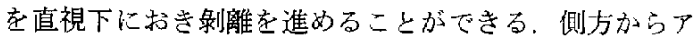
プローチ寸る経天幕法 ${ }^{47}$ ，経迷路法 ${ }^{27}$ ，経迷路 経天幕 法等の手術死亡率は低いが，本法ではさらに広い手術 野で大腫瘍に对しても安全確実に手術操作を行える，後 頭下法の術後の死亡原因江手術直後上りも数日後の腷幹 部硬塞浮腫が多いこ上は ${ }^{10398839342)}$ 後頭下法が脳幹部に対 して手術侵襲が大きく，危険が多いことを示している。

\section{2. 合併症}

術後の側頭葉下んか九は 経迷路経天幕法の Cabral \& King" では22\%であるが，著者らは大缠瑒に対してのみ 予防的鎮痓唎投与行い発生をみていない，迷路破壊の ためのめまい症状の訴えもなく，髄膜炎，髄液瘦の発生 も他の手術法による Adams ${ }^{13}$, Cook ${ }^{100}$, King ${ }^{31)}$, Yasar$\mathrm{gil}^{542}$ と比較しても多くない。 また本法による27例には 術後の後出血による再開頭むなく，経中頭蓋窩法に特有 と思われる合併症はみられなかった。

\section{Vおわりに}

小腷橋角部腫瘍特に聴神経腫湯に対する拡大中頭蓋窩
法（慶大変法）の手術手技の詳細と手術成䋶を述べた。 本法は高度の手術手技を要する特殊な手術法ではなく， 多くの利点をむつ優れた手術法である。本法による聴神 経腫瘍27例では手術死亡なく，現在まで退院後死亡もな $<$ ，術後合併症少なく，全摘出率 $63 \%$ ，全摘出と根治的 摘出と合わせ $778 \%$, 顔面神経俚全摘出上根治的摘出々 合加せて $67 \%$ に保存され，ほぼ満足す心゙き結果を得てい る。また本法は神経耳科と協同で行っているが，聴神経 腫場手術では腫黇が小さいほど operative mortality, postoperative morbidity が低いことから，神経耳科と神経 外科の密接な協力に上る早期䛦断と早期手術吕望まれ る。

\section{文献}

1) Adams, C. B. T.. Colman, B. H., Lund, W. S. \& WRIGHT, J. L. W. Comment on the combined translabyrinthine-transtentorial approach for acoustic neuroma. $J$ Laryngol Otol 88: 1101-1103, 1974

2) Antoli-Candela, F.: Acoustic neuroma. Selection of approach. Arch Otolaryngol 89: 334335,1969

3) Atkinson, W. J.: The anterior inferior cerebellar artery. Its variations, pontine distribution, and significance in the surgery of cerebellopontine angle tumors. $J$ Neurol Neurosurg Psychiatry 12: 137-151, 1949

4) Ballance, C.: Some points in surgery of brain and its membranes. London, Macmillan, 1907, 276p, Cjted by Pool, J. L. ${ }^{42)}$

5) Bell, C.: The nervous system of the human body. London, Longman, Reese, Orme, 1830 , $112 \mathrm{p}$, Cited by Pool, J.L. ${ }^{42}$ )

6) Borchardt, M.: Zur Operation der Tumoren des Kleinhirn-Bruckenwinkels. Klin Wischr 42 : 1033-1035, 1905

7) Bochenek, Z. \& Kukwa, A. : An extended approach through the middle cranial fossa to the internal auditory meatus and the cerebellopontine angle. Acta Otolaryngol 80:410-414, 1975

8) Bradley, W. H.: Techniques of acoustic neuroma surgery. Selection of approach. Arch Otolaryngol 89: 326-333, 1969

9) Cabral, R., King, T. T. \& Scott, D. F.: Incidence of postoperative epilepsy after a transtentorial approach to acoustic tumors. $J$ Neurol Neurosurg Psychiatry 39: 663-665, 1976

10) Cook, A. W. \& Browder, E. J.: Total removal of acoustic neuroma. Immediate and long term results. Arch Neurol 21: 7-14, 1969

11) Cotteril, J. M. : Cited by Rivella, A.G.46)

12) Cushing, H.: Tumors of the nervus acousticus 
and the syndrome of the cerebellopontine angle. Philadelphia, Sanders, 1917, 296p

13) Dandy, W. E.: An operation for the total removal of cerebellopontine (acoustic) tumors. Surg Gynecol Obstet 41: 129-148, 1925

14) DANDY, W. E.: Results of removal of acoustic tumors by the unilatcral approach. Arch Surg 42 : 1026-1033, 1941

15) Ditulio, M. V. \& Rand, R. W.: "Microneurosurgery". 2nd Ed. Edited by Rand, R.W., C V Mosby Co., 1978, $208 \mathrm{p}$

16) Drake, C. G.: Intracranial facial nerve reconstruction. Arch Otolaryngol 78: 456-460, 1963

17) Drake, C. G.: Total removal of large acoustic neurinoma. A modification of the McKenzie operation with special emphasis on saving the facial nerve. $J$ Neurosurg 26:554-561, 1967

18) Elsberg, C. A.: Cited by Pool, J.L. ${ }^{42}$

19) Fraenkel, J., Hunt, J. R., Woolsey, G. \& Elsnerg, C. A.: Contribution to the surgery of neurofibroma of the acoustic nerve, with remarks on the surgical procedure. Ann Surg 40:293-319, 1904

20) García-Bengochea, F. \& Kohut, R. I.: The subtemporal transtentorial approach for large acoustic nerve tumors. Acta Neurol Lat Am 18: $344-354,1972$

21) 白馬 明：Transpetrosal-transtentorial approach による小脳橋角部腫瘍摘出術．脳外 $6: 347$ $-354,1978$

22) Hegner, C. A. \& Z Zange, J.: Ueber die translabyrinthare Operation von Tumoren im Kleinhirnbruckenwinkel, zugleich ein Beitrag zur operativen Behandlung zerebraler Sehstorung. Klin Mblf Aughlk 56: 176-192, 1916

23) Hitselberger, W. E. \& House, W. F.: A combined approach to the cerebellopontine angle. A suboccipital-petrosal approach. Arch Otolaryngol 84: 267-285, 1966

24) Horrax, G. \& Poppex, J. L.: End results of complete versus intracapsular removal of acoustic tumors. Ann Surg 130: 567-575, 1949

25) Hot:se, W. F. : Surgical exposure of the middle cranial fossa. Laryngoscope 71:1363-1385, 1961

26) House, W. F.: Surgery of acoustic tumors. Otolaryngol Clin North Am 6:245-266, 1973

27) House, W. F.: Acoustic neuroma perspective, 1977. Laryngoscope 88: 816-820, 1978

28) Kanzaki, J., Kawase, T., Sano, K., Shiobara, R. \& Toya, S.: A modified extended middle cranial fossa approach for acoustic tumors. Arch Otorhinolaryngol 217: 119-121, 1977

29) 神崎 仁, 塩原隆造, 河瀬 斌, 任野公俊, 戸谷重雄：聴神経埂瘍の早期骖断および治療に 対する神経耳科的アプローチ． III. 怙大中頭蓋 窝経由法の変法について。耳喉50：19-28，1978
30) KING, T. T.: Combined translabyrinthinetranstentorial approach to acoustic nerve tumors. Proc R Soc Med 63: 780-782, 1970

31) KING, T. T.: Results and complications of translabyrinthine and transtentorial approaches to 60 acoustic nerve tumours. $J$ Neurol Neurosurg Psychiatry 38: 411,1975

32）小松㱦篤，相羽 正， 戸塚元吉：聴神経腫瘍 の早期診断ならびに嚚床症状と手術手技との関 連について.神経外科(Part II) 16：155-167，1976

33) Krause, F.: Surgery of the brain and spinal cord. Trans. H. A. Haubold. New York, Rebman, 1909, 282 p, Cited by Pool, J.L.42)

34) Kummes, W.: Otologische Gesichtspunkte bei der Diagnose und Therapie von Erkrankungen der hintercn Schadelgrube. Dtsch $Z$ Nervenheilk 36: $132-142,1909$

35) McKenzie, K. G. \& Alexander, E., JR., : Acoustic ncuroma. Clin Neurosurg 3: 21-36, 1955

36) Montgomery, W. W.: Surgery for acoustic neurinoma. Ann Otol 82: 428-444, 1973

37) Morrison, A. W. \& Krvg, T. T.: Experiences with a translabyrinthine-transtentorial approach to the cerebellopontine angle. Technical note. $J$ Neurosurg 38: 382-390, 1973

38) Northfield, D. W. C.: Surgical treatment of acoustic neurinoma. Proc $R$ Soc Med 63: 769-775, 1970

39) Olivecrona, H.: Acoustic tumors. I Neurosurg 26: 6-13, 1967

40) Panse, R.: Klinische und pathologische Mittelungen. IV. Ein Glioms des Akustikus. Arch Ohr Heilk 61: 251-255, 1904

41) Pool, J. L. \& PavA, A. A.: "Early diagnosis and treatment of acoustic nerve tumor". Charles C Thomas, Springfield, 1957

42) Pool, J. L., Pava, A. A. \& Greenfield, E. C.: "Acoustic nerve tumors. Early diagnosis and treatment". 2nd Ed., C C Thomas, Springfield, Illinois, $1970,127 \mathrm{p}, 134 \mathrm{p}, 168-173 \mathrm{pp}$

43) Quix, F. H.: Fin Acousticustumor. In III Niederlandische Gesellschaft fur Hals-, Nasenund Ohrenheilkunde. Arch Ohr Nas Kehlkopfheilk $82: 252-253,1911$

44) RaND, R. W.: "Microneurosurgery". C V Mosby Co. Saint Louis, 1969, 126-154 PP

45) Rand, R. W. \& Kurze, T.: Micro-neurosurgical resection of acoustic tumors by a transmeatal posterior fossa approach. Bull Los Angeles Neurol 30: 17-20, 1965

46) Revill A, A. G.: Neuromas of cerebellopontine recess. A clinical study of 160 cases including operative mortality and the results. Bull Johns Hopkins Hosp 80: 254-296, 1947

47) Rosomofr, H. L.: The subtemporal transtentorial approach to the cerebellopontine angle. 
Laryngoscope 81 ; 1448-1454, 1971

48) Sandifort, E.:Observationes anatomico-pathologicae. Lugduni Batavorum, 1777, Chapter 9, pp 116-120, Cited by Pool, J.L. ${ }^{42}$

49) Schmiegelow, E.: Beitrag zur translabyrintharen entferung der akustikustumoren. Z Ohrenheilk 73: 1-21, 1915

50) Seeger, W.: Atlas of topographical anatomy of the brain and surrounding structures. SpringerVerlag, Wien, New York, 1978, pp 464-471

51) Stieglitz. L., Gerster, A. G. \& Lilienthal, H.: A study of three cases of tumor of the brain in which operation was performed-one re- covery, two death. Am J Med Sci 111:509-531, 1896

52) Thомson, J.: Suboccipital removal of acoustic neuromas. Results of 125 operations. Acta Otolaryngol 81 : 406-414, 1976

53）九十九大造, 石田吉享, 中西 享, 㙁原隆造, 志沢寿郎, 戸谷重雄, 神崎 仁, 古賀慶次郎： 聴神経腫場の診断と手術法の選択，脳外 3:227 $-235,1975$

54) Yasargil, G. Y. \& Fox, J. L.: The microsurgical approach to acoustic neurinomas. Surg Neurol 2 : 393-398, 1974 